\title{
Koronavirüs Pandemisinin (Kovid-19) Toplumsal Etkileri
}

Social Effects of Coronavirus (Covid-19) Pandemic

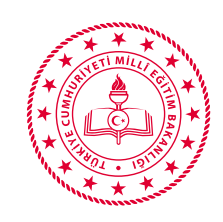

ANTALYA

IL MILLî EĞiTiM MÜDÜRLÜĞÜ

\section{Ramazan AHMADI ${ }^{1^{*}}$}

${ }^{1}$ Akdeniz Üniversitesi, Edebiyat Fakültesi, Sosyoloji Bölümü, Antalya / Türkiye

${ }^{1}$ Sociology Department, Faculty of Letters, Akdeniz University, Antalya / Turkey

*ramazan.ahmadi230@gmail.com

ORCID: 0000-0002-8299-7080

\author{
MAKALE BILLGISİ / ARTICLE INFORMATION \\ Geliş Tarihi / Date Received \\ 26.09.2020 \\ Yayın Tarihi / Date Published \\ Aralık / December 2020
}

\section{ATIF / CITE as}

Ahmadi, R. (2020). “Koronavirüs Pandemisinin (Kovid-19) Toplumsal Etkileri” / “Social Effects of Coronavirus (Covid-19) Pandemic”. bilar: Bilim Armonisi Dergisi, 3 (2): 65-72. doi: 10.37215/bilar.800484

\section{https://dergipark.org.tr/tr/pub/bilar}

Copyright (C Published by Antalya İl Millî Eğitim Müdürlüğü Since 2018, Antalya, 07100 Turkey. All rights reserved. 
Yeni tip koronavirüs salgını, küresel ölçekte toplumsal, kültürel, ekonomik ve siyasi sonuçları olan derin bir kriz ortaya çıkarmıştır. İnsanlar ve diğer canlılar için tehdit oluşturan bu salgının nasıl ortaya çıktığına ilişkin çeşitli iddialar mevcuttur. Virüsün yabani hayvan pazarında yayılmış olabileceğini iddia eden görüşlerin yanı sıra laboratuvar ortamında geliştirilmiş olabileceğine ya da biyolojik silah olarak kullanılabileceğine dair varsayımlar da bulunmaktadır. Yeni tip koronavirüsün ortaya çıkma sebebi ne olursa olsun bu süreç, mevcut küresel sistemin insan yaşamını tehdit etmekte olan yönlerini açıklıkla ortaya koymuştur. Sağlığın temel mesele haline gelmesi, toplumun hızla dijitalleşmeye doğru ilerlemesi, sosyal ilişki biçimlerinin değişmesi ve tüm ekonomik ve sanatsal faaliyetlerin yeniden biçimlenmesi gibi pandemi sonrasından bir takım yapısal dönüşümler meydana gelmiştir. Genel olarak toplumların sosyoekonomik yapısının dönüşmesi ve ülkeler arasındaki ilişkilerin yeni bir görünüm kazanması öngörülmektedir. Salgın ile birlikte toplumsal düzlemin yeniden inşa edilmesi gerekliliği açıkça ortaya çıkmıştır. Çalışma kapsamında sosyal, politik ve ekonomik alanlarda virüsün etkileri tartı̧̧ılmış ve bu küresel krizlerden çıkabilmek adına çeşitli öneriler geliştirilmiştir.
\end{abstract}

Anahtar Sözcükler: Dijitalleşme, Fiziksel mesafe, Koronavirüs, Kovid-19 Pandemi, Sosyal dayanışma.

\title{
ABSTRACT
}

The coronavirus pandemic, likened to a Third World War, has caused major crises all around the world. There are different rumors about how this pandemic, which poses a threat to humans and other living things, has come about. In addition to the views that the virus is transmitted from animals to humans, there are also assumptions that it is a man-made biological virus, which is claimed to have economic and political plans behind it. Regardless of the cause of the coronavirus, it emerges as one of the striking examples of the global world's threatening aspects to human life. Some of the changes that will emerge in the world after the coronavirus are that health becoming the main issue, society moving towards digitalization, social relations being altered, and all economic and artistic activities are being reshaped. Generally, it is predicted that the socio-economic structure of societies will transform and the relations between countries will gain a new view. The coronavirus crisis makes it clear that communities need to be rebuilt. In the scope of the study, the social, political, and economic effects of the virus have been discussed, and several proposals have been developed in order to overcome these global crises.

Keywords: Digitalization, Physical distancing, Coronavirus, Covid-19, Pandemic, Social solidarity. 


\section{Gíriş}

Çin'in Wuhan Eyaletinde 2019 yılının aralık ayında insanlarda akut solunum sendromu (Kovid-19) salginına neden olan yeni bir koronavirüs tipi (SARS-CoV-2) ortaya çıkmıştır (Zhou vd, 2020, 1054). Kovid-19, insanlar arasında hızla yaygınlaşarak etkilerini gösteren ve ölümcül sonuçları olan yeni tür bir salgın hastalıktır. Henüz tıp alanında kesin tedavi yöntemi olarak bir aşı tescil edilememiştir. Bununla birlikte Dünya Sağlık Örgütüne göre şu anda dünya çapında 176 aşı geliştirilmiştir. Aşıların 34'ü insanlar üzerinde test edilmeye başlanmıştır. Bunların arasında 8 aşının testleri son aşamadadır. Rusya, ağustos ayında koronavirüs aşısını geliştiren ve aşının yurt içinde kullanımına izin veren ilk ülke olmuştur. Rusya Sağlık Bakanı Mikhail Morashko, Rus Crohn'un aşısının antikor ürettiğini belirtmiştir. Buna karşılık diğer ülkelerdeki uzmanlar ve Dünya Sağlık Örgütü, Rus aşı testlerinin etkililiğini ve güvenliğini kanıtlamak için yeterli olmadığ yönünde söylemlerde bulunmuşlardır (BBC News 2020a). Bunlara rağmen Dünya Sağlık Örgütü ve tıp alanında çeşitli profesyoneller sadece bazı tedavi yöntemleri, korunmaya yönelik önlemler ve öneriler sunmuştur. Bu hastalık sonucunda dünya çapında kişisel hijyeni arttırma, maske takma ve fiziksel mesafeye dikkat etme gibi virüsün yayılmasına engel olabilmek adına çeşitli önlemler almaya yönelik çağrılar yapılmıştır. Toplumların sosyoekonomik yaşamlarını çeşitli yönleriyle etkileyen ve sarsici etkilerde bulunan koronavirüs, tüm dünyayı küresel düzeyde salgınla mücadele etmek için birleştirmiştir. Bu çalışma kapsamında bu yeni tip virüsün toplum üzerindeki etkileri farklı boyutlarıyla incelenecek ve bu krizden çıkabilmek adına toplumun yeniden inşa edilmesi gerekliliği üzerinde durularak çeşitli öneriler sunulacaktır.

\section{KORONAVIRÜS KRIZZiNIN SOSYOEKONOMIK SONUÇLARI}

Yeni tip koronavirüsün sosyal, politik, ekonomik ve kültürel alanlarda küresel boyutta çeşitli etkileri olmuştur. Çalışma kapsamında her bir boyut ayrı başlıklar altında incelenmiştir.

\subsection{Salgının Sosyal Yaşam Üzerindeki Etkileri}

Kişilerarası temas ile yaygınlık kazanan bu hastalık, kişilerin sosyal yaşamlarını ve ilişkilerini yeniden yapılandırmayı gerekli kılarak büyük etkilerde bulunmuştur. Fiziksel bağlamda gerçekleşen sosyal ilişkiler bir süre askıya alınmış, dijital platformlar vasıtasıyla devam ettirilmeye çalışılmıştır. Kendi sağlığımızın yanı sıra diğerlerinin sağlığını da korumak önemli bir mesele haline gelmiş ve diğerleri de sorumluluk alanı içerisine alınmıştır. Koronavirüs bir salgın olarak, doğal ilişkilerimizin eskisi gibi akıcı bir şekilde devam etmesi önünde bir engel olmuştur. Sağlıklı kalmak, temel mesele haline gelmiştir. Fiziksel mesafeler artsa dahi bu süreci atlatabilmek adına sorumluluk duygusuyla hareket edilerek topluluk duygusu güçlendirilmiştir.

Aileleri bir arada evde vakit geçirmeye zorlayan salgın süreci, aile ilişkilerinin de yeniden gözden geçirilmesini să̆lamıştır. Özellikle daha uzun süre evde kalmaya başlayan erkekleri, ev işi ve çocukların bakımı konusunda iş yükü ve paylaşımına ilişkin farkındalık kazandırmaya yöneltmiştir. Aynı zamanda ailecek geçirilen sürenin artmasıyla birlikte aile içi boş zaman değerlendirme ve vakit geçirme yöntemlerinde yeni arayışlara ve aile ilişkilerini kuvvetlendirmeye yönelik yeniden yapılanmalara sebep olmuştur.

Olumlu olası etkilerinin dışında, bazı medya raporlarına göre Koronavirüs krizi döneminde aile içi şiddet de artmıştır (Mohajer 2020). Gerçek şu ki daha az farkındalığın olduğu bir toplumda, sağlıklı bir aile kurma üzerine daha az çaba harcanmaktadır. Örneğin, Afganistan'da geleneksel ailenin ortalama üyesi 7 kişiden fazladır (Salahşur 2018). Üye sayısı 7 kişiden oluşan ailenin sağlık, beslenme, eğitim ve diğer sosyal ihtiyaçları yoksulluk oranlarıyla birlikte göz önünde bulundurulduğunda sağlıklı bir aile kurma olasılığının daha düşük olduğu görülmektedir. Karantina devam ederse, ekonomik kayıpların yanı sira hirsızlık, intihar ve aile parçalanması gibi sosyal sorunlara neden olması muhtemeldir.

Virüs, özellikle yaşlı ve kronik hastaların çok sayıda ölümüne neden olmaktadır (Deutsche Welle 2020a). Nüfus yapısında değişiklikler yaratan bu durum bazı ailelerin evin geçimini sağlayan fertlerini kaybetmesine sebep olacak ve ailelerin geçim sorunları yaşamasına ve yoksullaşmalarına neden olacaktir.

Pandemi süreci aynı zamanda toplu bir şekilde gerçekleştirdiğimiz tüm törenlerin önünde bir engel olmuştur. İnsanların acılarını paylaşarak azaltmalarını sağlayan, birlik ve dayanışmayı arttıran cenaze törenlerinin gerçekleştirilmesine kısıtlamalar getirilmiştir. Benzer şekilde düğünler ve çeşitli kutlamalar bir süre ertelenmiş ve çeşitli sınırlar içerisinde farklı biçimlerde devam ettirilmeye çalışılmaktadır.

Bu salgın, önyargıları azaltmak için fırsatlar yaratmaktadır. Bireyler, topluluklar ve hükümetler arasında hastalığın yayılması yönündeki koordineli çaba grupların ortak bir kadere sahip tek bir toplulukta bir araya gelmesini kolaylaştırabilecek güçlü iş birliği sinyalleri verebilir. Bu işbirlikçi eylemler salgından en az zararla çıkılmasını sağlayan en büyük yöntemlerden birisi olmaktadır. 
Bu hastalık insanların birbirine ne kadar ihtiyacı olduğunu göstermiştir.

İnsanların davranışları sosyal normlardan etkilenir: İnsan, başkalarının yaptıklarına ilişkin algıları ve başkalarının onayladı̆̆ı veya onaylamadıklarını düşündüğü şeylerdir (Cialdini ve Goldstein 2004, 614). Sosyal ağlar, bir salgin sırasında hem zararlı hem de faydalı davranışların yayılmasını artırabilir ve bu etkiler a ğ yoluyla arkadaşlara, arkadaşların arkadaşlarına ve hatta onların arkadaşlarının arkadaşlarına yayılabilir (Christakis ve Fowler 2013, 572). Koronavirüs hızlı bir şekilde kişiden kişiye yayılmaktadır. Büyük şirketlerde ve kalabalık iş merkezlerinde çalışanların temas ettikleri kişi sayısının fazla olması nedeniyle daha fazla risk söz konusudur (Christakis ve Fowler 2010, 2). Ancak ayn insanlar, hastalığı yavaşlatmak için de etkili olabilirler. Hijyen ve fiziksel mesafeyi koruma gibi olumlu müdahaleler ile hastalığın yavaşlatılması konusunda ciddi mücadeleler verilebilir.

Doksanlı yaşlarında olan Jürgen Habermas, günümüzün yaşayan en önemli felsefecilerden ve sosyologlardan birisidir. İki ciltlik "Felsefe Tarihi" çalışmasında Fransız gazetesi Le Monde ile yaptı̆̆ bir röportajda, küresel koronavirüs salgınının ahlaki ve entelektüel etkilerini araştırmış ve bu konuda insanın bilgi eksikliğini vurgulamıştır. Le Monde gazetesinin "Bu küresel hastalık krizi bize ahlaki, felsefi ve politik olarak ne öğretti?" sorusuna Habermas'ın yanıtı şu şekilde olmuştur: Felsefi olarak, bu küresel salgın herkesi düşünmeye ve eylemde bulunmaya teşvik etmiştir. Artık herkes harekete geçmelidir (Nedaye Azadi 2020).

Habermas, hükümetlerin veya uzmanların koronavirüs hakkında her şeyi bilmediklerini vurgulamaktadır. Hükümetler, onlara tavsiyede bulunan virologlarin sinırlı bilgiye sahip olduklarını ve bu sinırlı bilgiye dayalı kararlar almaları gerektiğinin farkındadır. Habermas, "Belki de bu nadir deneyimin kamu bilinci üzerinde etkisi vardır." demektedir (Nedaye Azadi 2020). Böylece yaşanan krizin bir kamu bilinci yaratma, canlandırma ve hareketliliği sağlama üzerinde etkili olabileceğine vurgu yapmaktadır.

\subsection{Salgın Döneminde Devlet Politikalarının Rolü ve Önemi}

Koronavirüs salgını ülke siyasetini, gündemini ve hükümet politikaları farklı boyutlarda etkilemiştir. Salgının ulaştığı boyut, hükümetlerin ciddi önlemler almalarını ve yaptırımlar uygulamalarını zorunlu hale getirmiştir. Hükümetlerin gerçekleştirdiği denetimler ve kısıtlamalar, pandemi sürecinin başarılı bir şekilde sonuçlanmasında temel belirleyicilerden birisi olmuştur. Koronavirüs hastalığının yayılması, seyahatleri kısıtlanması, yurtdışı yolculuklarının sayısının ve ülkelerdeki ekonomik aktivitelerin azaltılmasını gerekli kılmıştır. Bu salgın, bizlere küresel dünyada hâlâ ulus devletlerin önemli bir aktör olduğunu göstermiştir. Bu süreçte izlenen yaptırımlar sürecin atlatılma biçimini belirleyen temel unsur olmuş ve politikacıların halkı yönlendirmesi ve seferberlik sağlaması yönünde temel kaynak olmuştur. Hükümetler bilimsel tavsiyelerin 1şı̆̆ında, toplumun sağlığını korumak amacıyla çeşitli önlemler almaktadır. Türkiye örneğinde ele alındığında, kamu alanında geçici süreliğine esnek çalışma modeli benimsenmiştir. Eğitim faaliyetlerinin kısa bir süreliğine durdurulması ve ardından uzaktan eğitim modelleriyle alternatif bir şekilde devam ettirilmesine yönelik uygulamalara da hızla geçilmiştir. Gerekli teknik donanıma sahip olmayan öğrencilerin eğitim faaliyetlerini devam ettirebilmeleri adına tüm iletişim kanallarıyla mağduriyetlerini önlemeye yönelik düzenlemeler gerçekleştirilmiştir. Aynı zamanda sadece risk grubunda olan kişileri korumaya yönelik bazı kısıtlamalar ve taşıyıcılığı azaltmaya yönelik geçici süreyle önleyici uygulamalar gerçekleştirilmiştir. En çok etkilenen grup olan yaşlıları koruyabilmek adına uygulanan sokağa çıkma kısıtlamasında ihtiyaçlarını karşılamaya yönelik sağlanan personel desteği örneklerden sadece birisidir.

\subsection{Salgının Ekonomik Yaşam Üzerindeki Etkileri}

Kaynaklara erişimdeki eşitsizlikler hastalığın yayılmasını yavaşlatan önlemlere ve sağlık hizmetlerine ulaşılabilirliği etkiler. Temiz su ve temizlik malzemelerine erişim ve bunlara ulaşabilecek maddi imkânlar önemlidir. Sağlık güvencesi olmayan bireyler ve ekonomik dezavantaj sahibi olanlar, enfekte olduktan sonra sağlık hizmetine erişmekte zorlanma durumuyla karşı karşıya kalabilirler. Örneğin, ABD'deki ekonomik statü ve 1 rksal eşitsizlik, sağlık sistemi de dâhil olmak üzere sosyal kurumlara olan güven düzeylerini etkilemektedir. Irk ve etnik azınlıkların günümüzde hâlâ devam etmekte olan ayrımcılık deneyimleri vardır ve güvensizliğe yol açmaktadır (Alesina ve La Ferrara 2002, 231).

Koronavirüsün şu anki durumu toplum için büyük bir sorun haline dönüşmüştür. Küresel koronavirüs salgını sadece yüz binlerce insanı öldürmeyi değil, aynı zamanda milyonlarca insanın yemek kaynaklarını da elinden almıştır. Dünya ekonomisini zorlayan virüs salgını, yüzyılın en büyük ekonomi çatlağının yaşanmasına yol açmıştır (Hüşmandi 2020). Özellikle de yoksullukla mücadele edenlerin sağlıklı besinlere ulaşmalarını ve çalışmaya devam edebilmelerini büyük ölçüde etkilemiştir. Özellikle hizmet sektöründe çalışanların, pandemi döneminde kısıtlı, dönüşümlü çalışmaları ve 
işyerlerinin belirli bir süre kapalı olması, tüketimin azalması ve bazı alanlara yönlenmesine bağlı olarak zorluklar yaşanmasına neden olmuştur. Dolayısıyla gıdaya erişim en önemli meselelerden biri haline gelmiştir. Korona krizi gıda kaynaklarını alt sınıfın elinden almış ve bu sınıfı hastalıktan önce açlıktan ölme tehlikesiyle baş başa bırakmıştır.

Koronavirüs krizinin toplumun farklı kesimlerinde yarattığı ekonomik baskılar kısa vadeli ve uzun vadeli etkiler olarak ele alınabilir. Kısa vadede, bu konunun toplumun yoksul sınıfı üzerindeki etkisi oldukça açıktır ve çok düşük yaşam geliri olan bu sınıf en fazla zararı yaşamaktadır. Ancak uzun vadede, mevcut durumun devam etmesi toplumun orta ve üst sınıfının ekonomik baskıdan ve krizin sonuçlarından etkilenmesine neden olacaktır. Bu koşulların devam etmesi, ticaret, imalat, hizmet ve rekreasyon faaliyetleri de dahil olmak üzere birçok işletmenin uzun vadede kapanmasına neden olmuştur ve toplumda işsiz sayısı her geçen gün artmıştır. İşletmeyi kapatmak orta ve uzun vadede orta sınıf tasarruflarını azaltacaktır. Buna ek olarak, ticaretin ve turizm faaliyetlerinin zarar görmesine sebep olacaktır.

Virüsün küresel olarak yayılması sonucunda, birçok hükümet çeşitli tedbirler alarak çeşitli faaliyetleri askıya almıştır. Firmalar, restoranlar, üniversiteler, okullar ve ulaşım gibi çeşitli iş alanları faaliyetlerini ertelemiş ya da çalışma süresini azaltmıştır. Bu da çoğu ülkede benzeri görülmemiş bir işsizlik durumuyla kendisini göstermiştir. Örneğin, korona nedeniyle 2020 Mart ayında Amerika Birleşik Devletleri'nde 10 milyon insan (Deutsche Welle 2020b) ve İran'da 2 milyon kişi işini kaybetmiştir (Deutsche Welle 2020c). Krizin uzun vadede devam etmesi halinde işsizlik oranları etkilenecek ve çoğu ülkede milyonlarca insanı işsiz kalma ihtimali ile yüz yüze getirecektir. İşsizlik oranındaki keskin artış toplumun çeşitli kesimlerinin satın alma gücünü azaltacak ve ürünlere olan talebin de azalmasına neden olacaktır.

Turizm endüstrisi antik çağlardan beri dünya çapında yaygındır ve dünyadaki çoğu ülke için her zaman önemli bir gelir kaynağı olarak kabul edilmektedir. İtalya, Fransa, Amerika Birleşik Devletleri, Türkiye ve diğer ülkelerde olduğu gibi turizm endüstrisi ekonomik büyümedeki anahtar değişkenlerden biridir. Gelir elde etmede oynadığı rol göz önüne bulundurularak hükümetler tarafından dünyanın dört bir yanından turistleri çekmek için çeşitli planlamalar yapılmaktadır. Fransa, İspanya ve ABD 2018 yılının dünyanın dört bir yanından en çok turist çeken üç ülkesi olmuştur (Rasuli 2020). Turizm sektöründe 2018 yılında Çin, Amerika Birleşik Devletleri ve Almanya sirasiyla 277 milyar dolar, 144 milyar dolar ve 94 milyar dolarla en fazla harcama yapan ilk üç devlet olmuştur (Rasuli 2020). İstatistikler, turizm endüstrisinin ülkelerdeki önemini göstermektedir. Virüsün ortaya çıkmasından sadece birkaç gün sonra, ev karantinası virüsle başa çıkmanın tek yolu olarak kabul edildi. Virüsün yaygın olduğu hemen hemen her ülkede, karantina hükümetler tarafından virüsün yayılmasını önlemek için zorunlu bir uygulanma olarak kullanılmaya başland1. Buna ek olarak Fransa, İspanya, ABD, Almanya ve Türkiye gibi pek çok ülke sınırlarını yabancilara kapattı veya büyük kısıtlamalar getirdi. Uluslararası uçuşlardaki önemli azalma (2019'da günlük 200.000 uçuştan Mart ayında uçuşların 60.000'e düşürülmesi - Flightradar), sınırların kapanması ve çoğu ülke tarafından uygulanan seyahat kisıtlamaları sonucunda turizm endüstrisi bu krizden ciddi boyutta etkilenmiştir (Rasuli 2020). Kuşkusuz bir gelir kaynağı olarak turizm endüstrisine büyük ölçüde bağımlı olan tüm ekonomiler oldukça olumsuz etkilenmiştir. Krizin sonu henüz belli olmasa da turizm endüstrisine yapılan ekonomik darbeyi telafi etmenin yıllarca sürmesi beklenmektedir.

\section{KORONAViRÜS KRIZZININ NEDENLERI VE TOPLUMUN YENIDEN INŞA EDILMESININ GEREKLiLiĞi}

Yeniden sosyal yapılanma süreci, toplumsal yapının bütünlüğünün birçok açıdan tehdit altında olduğu durumlar ile başlar. Irkçılık, savaş, eşitsizlik, yoksulluk, küresel 1sınma, suç, siyasi yolsuzluk, nüfus patlaması, enerji sıkıntısı, yetersiz sağlık hizmetleri ve işsizlik gibi sorunlar değişimi zorunlu kılan ve sağlıklı bir toplum yapısı oluşturmanın önündeki en önemli engellerden bazılarıdir.

Eğitim, toplumun yeniden yapılandırılabilmesinin en etkili araçlarındandır. Counts ve Giroux bunu şu şekilde ifade etmektedir: Bugün, sosyal kurumlar parçalandıkça ve toplum varlığını tehdit eden derin yaralarla sarsıldıkça, birçok kişi eğitimin güvenliğe giden tek doğru yolu sunacağı üzerinde durmaktadır. Eğitimcilerin sosyal ve ekonomik sorunların çözümünde liderlik rolü benimseyerek çalışmalarını demokrasinin zarar görmesini engellemek ve kamusal yaşama fayda sağlamak için gerçekleştirmelidirler (Schiro 2007, 133-134).

Yeniden sosyal yapılandırma, eğitim önderliğinde yeniden canlandirılırsa insanları sosyal sorunları analiz etme ve anlama, bu sorunların var olmadı̆̆ 1 bir dünya öngörme ve bu vizyonu hayata geçirmek için harekete geçme gücüne sahip olduğunu varsayar. Böylece, uygun şekilde yeniden canlandirılan okullarda eğitim bireylerin ve dolayısıyla toplumun dönüşümü için en büyük ümit ışığı olabilir.

Pandemiyle şekillenen günümüzün şartları doğrultusunda toplumu yeniden şekillendirmek 
önlemler eşliğinde büyük bir adım atılmasını gerektirmektedir. Elitlerin, entelektüellerin ve yöneticilerin toplumun refahı adına çaba göstermeleri son derece önemlidir.

Küresel korona krizin sona ermesiyle birlikte iki ihtimal öngörülmektedir: Ya totaliter ve otoriter rejimlerin sayısı büyük ölçüde artacak ya da toplumlarda daha insani koşullar oluşturmaya yönelik yeniden yapılanma sürecine gidilecektir. Buna ilişkin örneklerden olarak yoğun baskı ve yorgunluk altında çalışan İtalyan sa ğlık personeline yardımcı olmak için Lombardiya bölgesinde elli iki Küba doktorunun görevlendirilmesi gösterilebilir. Almanya ise gelişmiş tıbbi sistemi ile Yunanistan'a bile yardım edememiştir (Chomsky 2020). Siyasi alanda toplumun, insan ilkeleri ve insan haklarina uygun olarak ulusal ve uluslararası alanlarda ilişkiler sağlayabilecek demokratik bir siyasi sisteme ihtiyacı vardır. Böylece siyasi boyutta ülkeler arasındaki insan etkileşiminin yolu açılmalıdır.

Mevcut durumda insanların birbirleriyle daha fazla işbirliğine ihtiyacı vardır ve insanlar, kuruluşlar ve hükümetler koronavirüse karşı dayanışma ve empati ile mücadele etmeli, muhtaç insanlar ve ülkelerle işbirliği yapmalıdır. Türkiye, koronavirüs ile mücadelede en iyi işbirliği sağlayan ülkelerden birisidir. Türkiye Dişişleri Bakanı Mevlüt Çavuşoğlu 18 Nisan'da 116 ülkenin yardım başvurusunda bulunduğunu ancak Türkiye'nin bugüne kadar 44 ülkeye yardım edebildiğini söylemiştir (BBC News 2020b). Anadolu Ajansı ve $B_{B C}$ ye göre, Çin, ABD, İtalya, İspanya, İngiltere, İran, Sirbistan, Afganistan, Nijerya, Venezuela, Sudan, Somali, Irak, Azerbaycan, Kazakistan, Kolombiya, Arnavutluk ve Filistin, koronavirüsle mücadele için Türkiye'den vantilatör, maske, korona tespit kitleri, koruyucu giysiler ve diğer tıbbi ekipmanlar gibi ihtiyaç paketleri teslim almıştır (Altuğ 2020).

İnsanlığın görünmez düşmanını ortadan kaldırmak için tüm güçlerimizi bir araya getirmeliyiz. Bu nedenle, sömürmek, kışkırtmak ve yaptırımlar uygulamak yerine tüm dünya ülkelerinin tek yürek olarak ittifak kurması, insanların yaşamlarını iyileştirmek için güçlerini ve potansiyellerini birleştirmeleri gerekmektedir.

Bugün insanlar için koronavirüsün neden olduğu sağlık krizi çok tehlikeli ve ciddidir. Yeterli önlemler alınmazsa yaşanabilecek olası daha ciddi sonuçları da olabilir. Ancak bu kriz geçicidir ve elbette çözüme kavuşturulacaktır. İnsan varlığını bir anda yok edebilme ihtimali bulunan çok daha kalıcı ve ciddi iki krizle karşı karşıyadır: Nükleer savaş ve küresel 1sınma. Günümüzde aralarına eklenen koronavirüs kriziyle birlikte bu 3 kriz, neoliberal politikaların ortaya çıkardığı tehlikelerdir ve her geçen gün etkilerinin daha da artacağ 1 beklenmektedir.

İnsanlık tarihi hiç olmadı̆̆ 1 kadar tehdit altındadır. Tüm derin ekonomik, sosyal ve politik kargaşanın kaynağı neo-liberal ve küresel pazar politikalarından kaynaklanmaktadır. Bu anlar sadece koronavirüs ile mücadeleden değil aynı zamanda küresel sistemlerin eksikliklerinin ve insanlığın geleceğini iyileştirmek için değişmesi gereken ekonomik sistemin gerekliliğine ilişkin bir çağrıdır. Dolayısıyla koronavirüs gelecekteki felaketleri önlemek için bir uyarı ve alarmdır. Ancak, dünyada iki milyardan fazla insanı izole eden karantinanın bugüne kadar benzersiz olmadığ 1 , insanlığın yıllardır bu tür yıkıcı sosyal izolasyonla rahatsız olduğu kabul edilmelidir. Bugün bunu açıkça hissediyoruz. Ülkelerin karşı karşıya kaldı̆̆1 bu krizlerden öğrendiği ve çıkarsadı̆̆ 1 pek çok sonuç söz konusudur. Bu nedenle, farklı alanlarda yeniden düşünmek ve sosyal refahı güçlendiren ve krizleri daha iyi yöneten bir toplumun temelleri atılmalıdır. Toplumun tüm kesimleri arasında hiç olmadı̆̆ 1 kadar sosyal dayanışmaya ihtiyaç duyulmaktadır. Bu durum ayrımcılık ve önyargıyı ortadan kaldırmaya yönelik eşit bir yaşama atılabilecek ilk adım olabilir. Sosyal adaletin sağlanması ve ulusal birliğin güçlendirilmesi birçok sosyal sorunu azaltabilir ve ortadan kaldırabilir.

Bugünün dünyası dijital bir çağa doğru yol almaya başlamıştır. Bilgi ve teknoloji çağı olarak anılan 21. yüzyılda toplumsal yap1, teknoloji etrafında şekillenmektedir. Koronavirüs salgını ile birlikte toplumların dijitalleşmesi hızlanmış ve küresel ölçekte bütün sosyal sistemleri etkisi altına almıştır. Pandemi sürecinde sosyal ilişkiler, toplum sağlığını korumak için dijital platformlar aracılığıyla yeniden şekillenmeye başlamıştır. Ekonomik alanda ise işverenler ve çalışanlar için geleneksel çalışma biçimlerini değişme durumu, bu dönemde test edilmeye başlanmıştır. Bu dönemde uzaktan eğitim, esnek çalışma, e-ticaret ve evde çalışma da ön plana çıkmıştır. Turizm ve gida sektörleri de salgından ciddi şekilde etkilenmiştir. Salgınla birlikte hiçbir şeyin eskisi gibi olmayaca ğ muhakkaktır. Kovid-19, dijitalleşme adına hızla bir dönüşüm sağlamıştır. Bu imkânı doğru kullananlar ise geleceğin kazananları olacaktır (Kolukırık 2020, 28-32).

Ekonomik alanda ise ülkelerdeki ekonomik sistemi, zengin ve fakir arasındaki uçurumu bir dereceye kadar azaltacak ve serbest rekabet piyasasında reform yapilabilecek ve hükümetin doğrudan kontrole sahip olabileceği bir sistem oluşturulabilmesi için çaba gösterilmelidir. İşçi gelirleri ile işveren arasında göreceli bir denge kurulmalı, böylece işçi sınıfının kritik durumunda yoksulluk ve açlıktan mustarip 
olmasının önüne geçilecek önlemler alınmalıdır. Sosyal devlet uygulamaları geliştirilerek eşitsizlik dengelenmelidir. Özellikle bu kriz dönemlerinden çıkabilmek adına serbest piyasa rekabetinin iyileştirilmesi, işçilerin ve işverenlerin gelirleri arasındaki nispi dengenin sağlanması ve eşitsizliğin dengelenmesi oldukça önemlidir.

\section{SONUC}

Koronavirüs, tüm dünyada hızla yayılmış ve küresel bir kriz yaşanmasına sebep olmuştur. Birçok ülke kriz sonucunda sosyal, politik ve ekonomik alanlarda birçok sorunla karşılaşmıştır. Politik olarak koronavirüs çoğu ülkenin yönetim krizine girmesine neden olmuştur. En büyük vurgunun yaşandığı alan ise ekonomidir. Dünya çapında üretim ve tüketim alanında gerileme yaşanmış, ticaret ve turizm faaliyetleri askıya alınmıştır. Yoksulluk dolayısıyla toplumsal eşitsizlik artmıştır. Ülkeler uzun yıllar onarılamaz bir ekonomik gerileme yaşamıştır.

Koronavirüs patlak verdikten kısa bir süre sonra sosyal, ekonomik ve politik alanda insan yaşamının pek çok alanında etkisini açıkça göstermiştir. Spor yarışmalarına ara verilmesi, karantina uygulamaları, seyahat kısıtlamaları, okulların ve üniversitelerin kapatılması ve birçok üretim faaliyetinin geçici süreliğine durdurulması salgının görünür sonuçlarından sadece bazılarıdır.
Korona krizini yeni bir Rönesans olarak yorumlayabiliriz; Rönesans dini inançlara meydan okur ve insan sağlı̆̆ını bilimsel teorilerin merkezine koyar. Mevcut toplum da dijital bir toplum haline gelmiştir. Bir başka deyişle dijital hizmetler tüm sosyal, politik ve ekonomik boyutlarda kendisini göstermeye başlamıştır.

$\mathrm{Bu}$ dönemden sonra çevre sağlığı açısından çarpıcı değişiklikler olacak ve mobilya gibi çeşitli eşyalar dahi insan sağlığını ve refahını tespit etmek için tasarlanacaktır. Sağlık temel mesele haline gelecektir. Yaşanan teknolojik gelişmeler bireylerin sağlığını eskiye kıyasla kuşkusuz daha iyi yönde etkilemiştir. Ancak korona örneğinde yaşandı̆̆ 1 üzere küreselleşen dünya yeni tehlikelere de kapı aralamıştır.

Koronavirüs, elbette toplumsal yapı ve işleyiş üzerine yeniden düşünmeleri için bir fırsat sunmaktadır. Farklı ülkeler farklı sosyal, politik, ekonomik ve kültürel sorunlarla karşı karşıyadır ve bu sorunlara karşı mücadele, bilim insanlarını mevcut sosyal yapıyı değiştirmeye itmiştir. Küresel krizden geçmek için sorunlar giderilerek toplum yeniden inşa edilmelidir ve toplumlarının refahına, esenliğine ve barışçıl yaşamına yön veren yeni bir toplumun inşası için düzenlemeler gerçekleştirilmelidir. Eğitim aracılığıyla toplumlarının krizin üstesinden gelebilmek adına ekonomik, sosyal ve politik ihtiyaçların karşılanabileceği alternatif planlar üzerinde çalışılmalıdırlar.

\section{KAYNAKLAR}

Alesina, A., La Ferrara, E. (2002). "Who trusts others?". Journal of Public Economics, 85: 207-234.

Altuğ, B. (2020). “Dünya Sağlık Örgütünden Türkiye'nin gönderdiği tıbbi yardımlara övgü". Anadolu Ajansı.Erişim adresi:https://www. aa.com.tr/tr/dunya/dunya-saglik-orgutundenturkiyenin-gonderdigi-tib bi-y a r d imlar aovgu/1858699. Son Erişim Tarihi: 30 Mayıs 2020.

BBC News. (2020a). “Rusya'nın Crona aşısı 'antikor' üretiyor". Erişim adresi: https://www.bbc.com/ persian/world-54040170. Son Erişim Tarihi: 05 Temmuz 2020.

BBC News. (2020b). “Korona; Türkiye küresel yardım göndererek yumuşak gücünü gösteriyor". Erişim adresi: https://www.bbc.com/persian/ world-features-52390341. Son Erişim Tarihi: 23 Nisan 2020.
Chomsky, N. (2020). "Chomsky On Koronavirus: Why Neoliberalism and Big Pharma Can't Respond". WORDCRUNCH. Erişim adresi: https:// worldcrunch.com/koronavirus / chomsky-onkoronavirus-why-neoliberalism-and-big-pharmacan39t-respond. Son Erişim Tarihi: 29 Mart 2020.

Christakis, N. A., Fowler, J. H. (2010). "Social network sensors for early detection of contagious outbreaks". PLOS One, 5 (9): 1-8.

Christakis, N. A., Fowler, J. H. (2013). "Social contagion theory: examining dynamic social networks and human behavior". Statistic in Medicine, 32: 556-577.

Cialdini, R. B., Goldstein, N. J. (2004). "Social influence: compliance and conformity". Annual Review of Psychology, 55: 591-621. 
Deutsche Welle. (2020a). "Korona; Hangi gruplar en çok riskte? İstatistikler ne söylerdir?". Erişim adresi: https://p.dw.com/p/3ZCTN. Son Erişim Tarihi: 11 Mart 2020.

Deutsche Welle. (2020b). “Korona sonucu; Yalnızca mart ayında, Amerika Birleşik Devletleri'nde 10 milyon insan işini kaybetti". Erişim adresi: https://p.dw.com/p/3aPZR. Son Erişim Tarihi: 03 Nisan 2020.

Deutsche Welle. (2020c). “İran' da Korona nedeniyle 2 milyon kişi işini kaybetti". Erişim adresi:https: / / p. dw.com/p/3fX5p. Son Erişim Tarihi: 18 Temmuz 2020 .

Hüşmandi, Ş. (2020). “Koronavirüsün yayılmasının dünyadaki ekonomik eşitsizliklere etkisi". BBC News, Erişim adresi: https://www.bbc.com/ persian/business-52714782. Son Erişim Tarihi: 18 May1s 2020.

Kolukırık, S. (2020). “Dijitalleşmeye iten pandemi: COVID-19". Katılım Finans Dergisi, TKBB'nin Kuramsal İletişim Yayını, (21).

Mohajer, S. (2020). “Evelerin çatısı altında Korona Krizi". BBC News, Erişim adresi: https://www.bbc. com/persian/iran-features-52182085. Son Erişim Tarihi: 06 Nisan 2020.

Nedaye Azadi. (2020). “Jürgen Habermas: “Bu krizde, bilgisizliğimizin açık bilgisiyle hareket etmeliyiz"". Nedayeazady.org, Erişim adresi: http: / / nedayeazady.org / 2020 / 04 / 23 / \% D9\% 87\% D 8\% A 7\% D 8\% A 8\% D 8\% B 1\% D 9\% 85\% D 8\% A 7\% D 8 \% B3-\% D8\% AF\% D8\% B1-\%D8\% A7\% DB\% 8C\%D9\% 86$\%$ D8\% A 8\% D8\%AD. Son Erişim Tarihi: 23 Nisan 2020.
Rasuli, M. H. (2020). “Korona yaygınlığının Afganistan ve dünya üzerindeki ekonomik etkilerinin araştırılması". 8am.af News, Erişim adresi: https: / / 8 am.af/investigating-theeconomic-effects-of-the-korona-outbreak-onafghanistan-and-the-world-economy/. Son Erişim Tarihi: 14 Nisan 2020 .

Salahşur, H. (2018). “Afgan hükümeti artan nüfus konusunda uyarısı". Anadolu Ajansı, İstanbul, Erişim adresi: https://www.aa.com. $\mathrm{tr} / \mathrm{fa} / \%$ D $8 \%$ A $7 \%$ D $9 \% 81 \%$ D $8 \%$ B A $\%$ D $8 \%$ A 7 \% D $9 \% 86 \%$ D $8 \%$ B 3 \% D $8 \%$ A A $\%$ D $8 \%$ A $7 \%$ D $9 \%$ $86 / \%$ D $9 \% 87 \%$ D $8 \%$ B $4 \%$ D $8 \%$ A F $\%$ D $8 \%$ A $7 \%$ D $8 \%$ B $1-\%$ D $8 \%$ A F $\%$ D $9 \% 88 \%$ D $9 \% 84 \%$ D $8 \%$ A A $\%$ D $8 \%$ A $7 \%$ D 9\% $81 \%$ D $8 \%$ B A $\%$ D $8 \%$ A $7 \%$ D $9 \% 86 \%-$ D $8 \%$ B $3 \%$ D $8 \%$ A A $\%$ D $8 \%$ A $7 \%$ D $9 \% 86-$ $\%$ D $9 \% 86 \%$ D $8 \%$ B 3\% D $8 \%$ A $8 \%$ D $8 \%$ A A $\%$ D $8 \%$ A 8\% D9\% 87-\%D8\%B 1\%D8\% B4\%D8\%AF-\%D 8 \% B 1\% D9\% $88 \%$ D $8 \%$ B 2\% D 8\% A 7\% D9\% 81\% D 8\% B2 \% D9\% 88\% D9\% 86-\% D 8\% AC\% D9\% 85\% D 8\% B9\% DB \% 8C\% D 8\% AA-\% D 8\% A7\% DB \% 8C \% D9\% 86-\%DA \% A9\%D8\%B4\%D9\%88\%D8\%B1/1206620. Son Erişim Tarihi: 17 Temmuz 2018.

Schiro, M. S. (2007). "Curriculum Theory". Boston College, USA, SAGE Publication Inc, Erişim adresi: https: / / us.sagepub.com/sites / default / files / upmassets/16266_book_item_16266.pdf.

Zhou, F. Yu, T., Du, R., Fan, G., Liu, Y., Liu, Z., Xiang, J., Wang, Y., Song, B., Gu, X. Guan, L., Wei, Y., Li, H., Wu, X., Xu, J., Tu, S., Zhang, Y., Chen, H., Cao, B. (2020). "Clinical course and risk factors for mortality of adult inpatients with COVID-19 in Wuhan, China: A retrospective cohort study". The Lancet, 395: 1054. 